\title{
ReSEARChArTicle
}

\section{Management of bacterial wilt of tomato caused by Ralstonia solanacearum by bacterial antagonists and botanicals}

\author{
C.R. JAHIR BASHA, C.P. MANJULA AND M.K. PRASANNA KUMAR
}

\begin{abstract}
SUMMARY
Study was undertaken to know the effective management strategy through novel bio control agents and botanicals against Ralstonia solanacearum a dreaded pathogen causing bacterial wilt of tomato. The study revealed that Bacillus subtilis was found to be most effective in inhibiting the growth of the pathogen followed by Pseudomonas fluorescens, by producing an inhibition zone of $22.50 \mathrm{~mm}$ and $18.00 \mathrm{~mm}$ in diameter, respectively under in vitro conditions. However, among plant extract tested Isabgol seed extract was found to be highly inhibitory to the growth of the pathogen in which inhibition of 22.00, 19.50 and $18.00 \mathrm{~mm}$ was observed at 1:0, 1:1 and 1:5 dilutions. Similarly under field condition, Bacteriophages and Bacillus subtilis were found to be very effective in reducing the disease incidence by 72.50 per cent and 64.58 per cent with reduced soil population of the pathogen both in soil and rhizosphere
\end{abstract}

Key Words : Ralstonia solanacearum, Bacterial antagonists, Botanicals

How to cite this article : Basha, C.R. Jahir, Manjula, C.P. and Kumar, M.K. Prasanna (2017).Management of bacterial wilt of tomato caused by Ralstonia solanacearum by bacterial antagonists and botanicals. Internat. J. Plant Sci., 12 (2): 114-119, DOI: 10.15740/HAS/IJPS/12.2/114-119.

Article chronicle : Received : 03.04.2017; Revised : 21.04.2017; Accepted : 07.05.2017

\section{MEMBERS OF THE RESEARCH FORUM}

Author to be contacted :

C.R. JAHIR BASHA, Department of Plant Pathology, University of Agricultural Sciences, G.K.V.K., BENGALURU (KARNATAKA) INDIA

Address of the Co-authors:

C.P. MANJULA AND M.K. PRASANNA KUMAR, Department of Plant Pathology, University of Agricultural Sciences, G.K.V.K., BENGALURU (KARNATAKA) INDIA 